Note

\title{
Closely-related Xanthomonas citri subsp. citri isolates trigger distinct histological and transcriptional responses in Citrus limon
}

\author{
Ingrid Georgina Orce ${ }^{1}$, Mario Debes², Lorena Sendín ${ }^{1}$, Ana Luque², Marta Arias²,3, Adrián Vojnov5, María Marano ${ }^{4}$, Atilio $^{2}$ \\ Castagnaro $^{1}$, María Paula Filippone ${ }^{1 *}$
}

\author{
'Obispo Colombres Agro-Industrial Experimental Station/ \\ National Scientific and Technical Research Council/Institute \\ of Agro-Industrial Technology of Northwestern Argentina, Av. \\ William Cross, 3150 - Las Talitas, Tucumán - Argentina. \\ ${ }^{2}$ National University of Tucuman/Faculty of Natural Science/ \\ Miguel Lillo Institute, Miguel Lillo 205, C.P. 4000 - San \\ Miguel de Tucumán, Tucumán - Argentina. \\ ${ }^{3}$ National University of Catamarca/Faculty of Natural and \\ Exact Sciences, Maximio Victoria 55, C.P. 4700 - San \\ Fernando del Valle de Catamarca, Catamarca - Argentina. \\ ${ }^{4}$ National University of Rosario/Faculty of Biochemistry and \\ Pharmacy/Institute of Molecular and Cellular Biology of \\ Rosario, Suipacha 590, S2002LRK - Rosario - Argentina. \\ 5Institute of Science and Technology "Dr. Cesar Milstein"/ \\ National Scientific and Technical Research Council, 2468 - \\ C1440FFX - Ciudad Autónoma de Buenos Aires - Argentina. \\ *Corresponding author <paulafilippone@eeaoc.org.ar>
}

Edited by: Claudio Marcelo Gonçalves de Oliveira

Received October 29, 2015

Accepted February 25, 2016
ABSTRACT: Citrus canker, caused by Xanthomonas citri subsp. citri (Xcc), has an important economic impact on the citrus industry. Extensive information is available about the disease but, nevertheless, the study of plant-pathogen interactions could provide new information in the understanding of citrus canker disease. A new isolate has been identified, Xcc $A^{\top}$, which has a high genetic similarity (> $90 \%$ ) to the virulent $X_{c c}$ T strain based on genetic clustering analyses of the rep-PCR fingerprinting patterns, but it does not produce cankerous lesions in Citrus limon. In this study, we compared $C$. limon responses to $X c c A^{\top}$ and to the virulent $X c c T$ strain at both histological and transcriptional levels. Histologically, leaves inoculated with Xcc $A^{\top}$ exhibited neither a typical disordering of the spongy mesophyll, nor a swelling of epidermis. A particular content (undetermined) was also found in mesophyll cells near the stomata, together with increased starch accumulation. The transcriptomic profiles were compared by cDNA-AFLP technique. A total of 121 fragments derived from transcript (TDF) were either specifically induced or repressed by the isolates, and 62 were sequenced. Analysis of global expression identified different classes of genes known to be involved in plant-pathogen interactions. This study constitutes the first approach of the specific interaction between the avirulent $X_{c c} A^{\top}$ isolate and $C$. limon.

Keywords: cDNA-AFLP, gene expression, canker, plant defense, microscopy

\section{Introduction}

Asiatic citrus canker, caused by the bacterial plant pathogen Xanthomonas citri subsp. citri $(X c c)$, is a widespread disease that affects most commercial citrus species and varieties. Xcc infects hosts through natural openings, such as stomata and lesions in plant tissue, producing pustule-like cankers on leaves, stems and fruits (Brunings and Gabriel, 2003) and defoliation, blemished fruit, premature abscission and fruit drop in severe infections, all of which results in crop loss. Because $X c c$ is a quarantine pathogen in many countries, the impact of the disease on commerce is the most serious consequence, as there are restrictions on interstate and international fruit trade from canker-affected areas are imposed (Gottwald et al., 2002; 2009).

The disease is present in the Americas, where it first appeared in Brazil, and soon spread to other important citrus producing countries, such as Argentina, one of the world's largest lemon producers. Extensive information is already available about the disease, its epidemiology, the susceptibility of host genotypes and, in particular, the Xcc pathogen (Gottwald, 1993; Gra- ham et al., 2004; Van Sluys et al., 2002; Vojnov et al., 2010). However. the study of plant-pathogen interactions could provide new information in the understanding of citrus canker disease.

Chiesa et al. (2013) identified a new Xcc isolate with a high genetic similarity ( $>90 \%$ ) to the virulent $X c c \mathrm{~T}$ strain based on genetic clustering analyses of the fingerprinting patterns generated by $\mathrm{BOX}$, repetitive extragenic palindromic (REP), and enterobacterial repetitive intergenic consensus (ERIC) polymerase chain reaction (PCR) (repetitive elements-based [rep]PCRs). Named Xcc $\mathrm{A}^{\mathrm{T}}$, this isolate does not produce cankerous lesions in a host-specific interaction with $C$. limon, and is deficient in extracellular polysaccharide (EPS) xanthan production and induces an oxidative burst and a defense response in C. limon, independent of supplementation with exogenous xanthan (Chiesa et al., 2013).

In this study, we compared $C$. limon responses to $X c c \mathrm{~A}^{\mathrm{T}}$ and the virulent $X c c \mathrm{~T}$ strain at both histological and transcriptional levels. The close genetic relationship between these two isolates could serve to understand the mechanism underlying resistance and susceptibility. 


\section{Materials and Methods}

\section{Plant material and inoculum preparation}

Six-month plants of Citrus limon (L.) Burm cv. Frost Eureka Nuclear were used to reproduce canker disease under controlled growth conditions. Plant leaves were inoculated with a bacterial suspension of $X c c \mathrm{~A}^{\mathrm{T}}$ or virulent

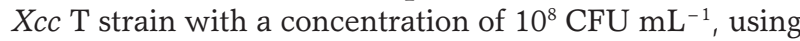
swab methods to mimic a natural Xcc infection process (Sendín et al., 2011). Inoculation with magnesium chloride $\left(\mathrm{MgCl}_{2}\right)$ was used as control. After inoculation, plants were covered with plastic bags and kept overnight, and then transferred to a growth chamber at $28^{\circ} \mathrm{C}$, with $70 \%$ relative humidity and a $16 \mathrm{~h}$ photoperiod.

\section{Light microscopy and cDNA-AFLP analysis}

For histological analyses, samples of inoculated leaves were taken at 0,3 and 7 days post-inoculation (dpi). Cross sections of these samples were stained with safranin, methyl blue and iodine (D`Ambrogio de Argüeso, 1986), mounted on slides in a solution of glycerin / water (50/50) and observed in a light microscope.

For transcriptional analyses, total RNA from inoculated leaves was prepared by $\mathrm{LiCl}$ precipitation (Sambrook et al., 1989). The cDNA-AFLP-based transcript profiling procedure was followed as prescribed by Vuylsteke et al. (2007), but with different restriction enzymes (MseI and EcoRI). Selective amplifications using the primers 5'-GACTGCGTACCAATTCANN-3' (EcoRI, where NN represents -GG, CT, GC, CC, AG, CA, AC and CG) and 5'-GATGAGTCCTGAGTAACMM-3' (MseI, where MM represents TT, AT, AC, AA TC, TA, AG and TG) were performed with a total of 64 selective primer combinations. Amplification products were separated on $5 \%$ polyacrylamide gels, reamplified and sequenced. Sequences obtained were compared with those shown by the BLASTn and BLASTx (NCBI, http://www.ncbi.nlm. nih.gov/BLAST), PHYTOZOME (http://www.phytozome. net), "ORANGE (Citrus sinensis) genome annotation" (http://citrus.hzau.edu.cn) and HARVEST (http://cgf.ucdavis.edu) searching engines. The expression level of eight TDFs randomly selected from Table 1 was quantified by quantitative real time retrotranscription-PCR (qRT-PCR) to validate the pattern of TDFs obtained with cDNAAFLP. qRT-PCR analyses were performed in a $25 \mu \mathrm{L}$ vol- ume containing $1 \mathrm{X}$ master mix (iQ SYBR Green), $0.4 \mathrm{uM}$ of each primer, and $4 \mu \mathrm{L}$ of 10 -fold cDNA dilutions. The relative expression of RNA transcripts was quantified with the threshold cycle value $(\mathrm{Ct})$ obtained from each sample by using the $2-\Delta \Delta \mathrm{Ct}$ method (Livak and Schmittggen, 2001), with a plant cytochrome oxidase (COX) gene for reference gene expression (Li et al., 2005).

\section{Results and Discussion}

Symptomatology and histology reveal differences in the interaction between $C$. limon and the closelyrelated $X c c \mathrm{~A}^{\mathrm{T}}$ and $X c c \mathrm{~T}$

Differential symptomatology was observed in young $C$. limon leaves treated with avirulent $\left(X c c \mathrm{~A}^{\mathrm{T}}\right)$ or virulent $(X c c \mathrm{~T})$ isolates. Seven days post-inoculation (7 dpi), Xcc T produced the typical circular water soaked lesions, in contrast with leaves inoculated with $X c c \mathrm{~A}^{\mathrm{T}}$, where circular dark spots were observed (Figure 1).

The differential symptomatology observed in $C$. limon after inoculation with $X c c \mathrm{~T}$ or $X c c \mathrm{~A}^{\mathrm{T}}$ was histologically analyzed by light microscopy. In leaf samples inoculated with Xcc T, it was observed that cells around the stomata were disorderly, intercellular space in the spongy mesophyll region had diminished, and leaf epidermal cells had swollen by 3 dpi (Figure 2A, B). By 7 dpi typical hyperplasia and hypertrophy of mesophyll cells were observed, with a consequent rupture of abaxial epidermis and bacteria oozing at the site of infection (Figure 2D, E). In contrast, in leaf samples inoculated with $X c c \mathrm{~A}^{\mathrm{T}}$ (Figure 2G, H, J), as well as in control leaves (Figure 2M, N, P, Q), the spongy mesophyll did not show disordering and epidermal cells had not swollen either by 3 dpi nor $7 \mathrm{dpi}$. However, the mesophyll cells near the stomata showed a particular content by 7 dpi in leaves inoculated with Xcc $\mathrm{A}^{\mathrm{T}}$ (not determined) (Figure 2K). The starch accumulation was higher in guardian cells of stomata in leaves inoculated with $X c c \mathrm{~A}^{\mathrm{T}}$, than in leaf tissue inoculated with $X c c \mathrm{~T}$ (Figure 2C, F, I, L). The highest amount of starch was observed at $3 \mathrm{dpi}$, but it dropped at 7 dpi (Figure 2I, L). In control leaves, cumuli of starch were not observed (Figure 2O, R). This reaction has been cited as a general plant response to different pathogen infections (Bertani et al., 2014; Pardo et al., 2012). Some evidence suggests that the wild $X c c$ strain presents in its
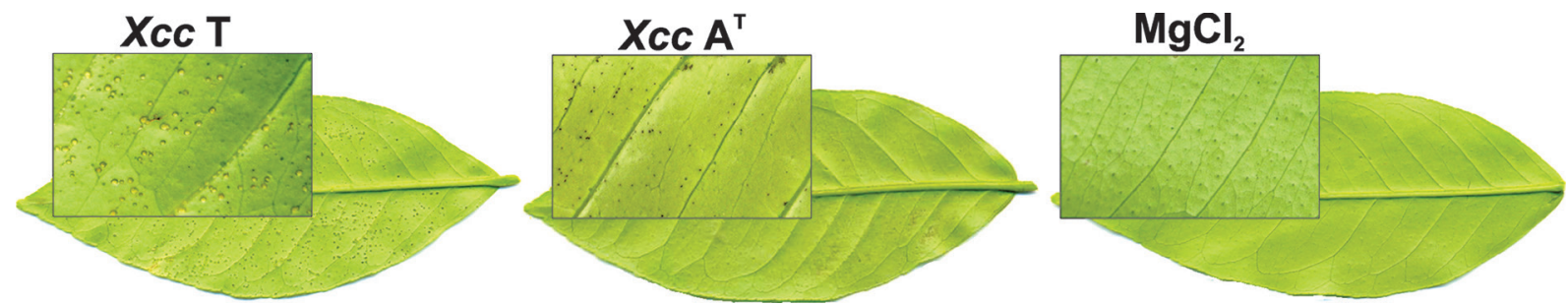

Figure 1 - Differential symptomatology induced in Citrus limon by Xcc T and $X_{c c} A^{\top}$. Foliar symptoms were observed at 7 days post-inoculation (dpi) in leaves inoculated with either Xanthomonas citri subsp. citri isolates, $X_{c c} \mathrm{~T}$ (left) or $\mathrm{Xcc} \mathrm{A}^{\top}$ (middle), and in mock inoculation with $\mathrm{MgCl}_{2}$ (right). 
Table 1 - Similarities of sequences of Citrus limon differentially expressed in response to either Xanthomonas citri subsp. citri isolates (Xcc T or $X_{C c} A^{\top}$ ) infection.

\begin{tabular}{|c|c|c|c|c|}
\hline & Length & $\begin{array}{l}\text { Accession number of } \\
\text { Highest similarity }\end{array}$ & & E value \\
\hline \multicolumn{5}{|c|}{ TDFs induced by $X c c A^{\top}$} \\
\hline Cit 11 & 361 & AAG49361.1 & Aminocyclopropanecarboxylate oxidase & $6.29 \mathrm{E}-02$ \\
\hline Cit 32 & 200 & Orange1.1 g 022529 m.g & Chlorophyll a/b binding protein & 2.90E-14 \\
\hline Cit 34 & 199 & Cs4g03600 & Plant recepetor-like Serine treonine kinase & $5.8 \mathrm{E}-02$ \\
\hline Cit 35 & 162 & Orange1.1 g $022529 \mathrm{~m} . \mathrm{g}$ & Mis 12 protein & $3.90 \mathrm{E}-05$ \\
\hline Cit 40 & 154 & Orange1.1 g $024610 \mathrm{~m} . \mathrm{g}$ & ATP10 Protein & $6.55 \mathrm{E}-02$ \\
\hline Cit 42 & 106 & EF377537.1 & Messenger RNA from leaves of Poncirus trifoliata & 7.00E-07 \\
\hline Cit 76 & 102 & EY734971.1 & Sweet orange fruit, development stadium, Citrus sinensis cDNA & 4.00E-04 \\
\hline Cit 77 & 103 & EU442614 & Citrus reticulata amplified fragment length polymorphism marker & $1.8 \mathrm{E}-02$ \\
\hline Cit 78 & 107 & Orange1.1 g 011573 m.g & ATPase family associated with various celular activities (AAA) & 4.16E-02 \\
\hline Cit 105 & 135 & Orange1.1 t 03117 & Putative beta-galactosidase 10 & 0.54 \\
\hline Cit 108 & 149 & Orange1.1 g $019667 \mathrm{m.g}$ & PRP38, splicing factor & 2.90E-06 \\
\hline \multicolumn{5}{|c|}{ TDFs induced by Xcc T } \\
\hline Cit 3 & 206 & ABL67650.1 & Miraculin like protein & 0.58 \\
\hline Cit 4 & 178 & EY701345.1 & Sweet orange fruit, development stadium, Citrus sinensis DNA copy & 0.36 \\
\hline Cit 6 & 126 & Orange1.1 g $008135 \mathrm{~m} . \mathrm{g}$ & HEC1 protein & $1.48 \mathrm{E}-02$ \\
\hline Cit 7 & 200 & EY823070.1 & Poncirus trifoliata leaf, infected with Citrus tristeza virus Citrus trifoliata cDNA, mRNA sequence & $3.0 \mathrm{E}-03$ \\
\hline Cit 26 & 212 & Orange1.1g025671 m.g & Chlorophyll a/b binding protein & 7.20E-11 \\
\hline Cit 27 & 204 & Orange1.1g015983 m & Leucine rich-repeat containing protein & $6.30 \mathrm{E}-138$ \\
\hline Cit 28 & 199 & EF377537.1 & $\begin{array}{l}\text { Poncirus trifoliata leaves } 1 \text { year old plants Citrus trifoliata cDNA clone S134 similar to phospho- } \\
\text { enolpyruvate }\end{array}$ & $6.00 \mathrm{E}-18$ \\
\hline Cit 29 & 80 & G0787079.1 & Citrus unshiu cDNA clone CuD09 similar to lipoxygenase, mRNA sequence & 0.13 \\
\hline Cit 41 & 126 & Orange1.1 g $038028 \mathrm{~m} . \mathrm{g}$ & Ciclin $\mathrm{H}$ & $1.10 \mathrm{E}-10$ \\
\hline Cit 43 & 60 & Cs2g10510 & MOR1 protein & 0.2 \\
\hline Cit 44 & 197 & Cs9g08940 & ARP8 protein & 0.053 \\
\hline Cit 55 & 55 & Cs7g08120 & DEAD-box ATP-dependent RNA helicase & 0.18 \\
\hline Cit 57 & 199 & HQ884142.1 & Linum sp. microsatelite sequence & $1.00 \mathrm{E}-06$ \\
\hline Cit 63 & 206 & Orange1.1 g 044905 m.g & Nitrogen metabolic regulation protein- related & 2.00E-20 \\
\hline Cit 64 & 207 & Cs9g08120 & Putative CVP2 like I inositol-1,4,5-trifosfate 5-fostfatase & $1.00 \mathrm{E}-27$ \\
\hline Cit 67 & 107 & Orange1.1 g $017810 \mathrm{m.g}$ & Putative serine esterase & 2.60E-17 \\
\hline Cit 72 & 216 & Scaffold00052 & Uncharacterized protein & $5.10 \mathrm{E}-56$ \\
\hline Cit 74 & 202 & Orange1.1 g $017810 \mathrm{m.g}$ & Ribosomal L7/L12 protein & 2.30E-09 \\
\hline Cit 85 & 566 & EF377537.1 & Fosfoenol piruvate carboxilase & $1.00 \mathrm{E}-12$ \\
\hline Cit 86 & 200 & Orange1.1 g $017810 \mathrm{~m} . \mathrm{g}$ & GTPase protein & 8.95E-02 \\
\hline Cit 89 & 200 & Cs2g030400 & Photosystem II related protein & 7.00E-26 \\
\hline Cit 92 & 402 & CX636796.1 & mRNA sequence from Poncirus trifoliata & 3.00E-134 \\
\hline Cit 94 & 378 & Orange1.1 g $037191 \mathrm{m.g}$ & Uncharacterized protein & $1.10 \mathrm{E}-73$ \\
\hline Cit 102 & 406 & Cs6g08490 & MYB transcrition factor & 1.00E-95 \\
\hline Cit 104 & 136 & Cs6g03890 & 1-0-Acylglucosa antocianin 0-Acyltransferase & $1.00 \mathrm{E}-04$ \\
\hline \multicolumn{5}{|c|}{ TDFs repressed by Xcc $A^{T}$} \\
\hline Cit 1 & 416 & orange1.1 g 018057 m.g & Transcription initiation factor TFIID subunit 8 & $3.60 \mathrm{E}-67$ \\
\hline Cit 5 & 174 & EY732374.1 & mRNA sequence from Citrus sinensis & 0.1 \\
\hline Cit 8 & 103 & ABX46354.1 & Resistance protein like nucleotide binding site-Leucine-rich repeat & 3.10E-02 \\
\hline Cit 9 & 77 & Orange1.1 g $000128 \mathrm{~m} . \mathrm{g}$ & Leucine rich- repeat protein & $1.50 \mathrm{E}-05$ \\
\hline Cit 16 & 87 & DN799236.1 & mRNA sequence from Citrus reticulata $\times$ Citrus temple & $1.00 \mathrm{E}-17$ \\
\hline Cit 25 & 200 & CD585758.1 & Poncirus trifoliata leaf, infected with CTV Citrus trifoliata cDNA, mRNA sequence & $1.00 \mathrm{E}-26$ \\
\hline Cit 62 & 197 & Orange1.1 g 0479 m.g & Serine/treonine Protein Kinase & $1.00 \mathrm{E}-24$ \\
\hline Cit 65 & 160 & XM_006470462.1 & Citrus sinensis protein AATF-like & 0.003 \\
\hline Cit 70 & 70 & EY675277.1 & Poncirus trifoliata leaf, infected with CTV Citrus trifoliata cDNA, mRNA sequence & 0.36 \\
\hline Cit 90 & 197 & Orange1.1 g 022614 m.g & SNARE protein & 3.10E-20 \\
\hline Cit 103 & 128 & CAP40294.1 & Putative beta galactosidase & 0.18 \\
\hline \multicolumn{5}{|c|}{ TDFs repressed by $X_{c c} T$} \\
\hline Cit 12 & 52 & AAK83559.1 & pY65, Putative resistance gene & $6.60 \mathrm{E}-01$ \\
\hline Cit 33 & 176 & ADE05307.1 & Actin protein & 0.41 \\
\hline Cit 97 & 209 & Scaffold00138 & Uncharacterized protein & $1.70 \mathrm{E}-55$ \\
\hline
\end{tabular}

${ }^{*}$ Those TDFs (fragments derived from transcripts) that not have similarities with known sequences were excluded from the table. 


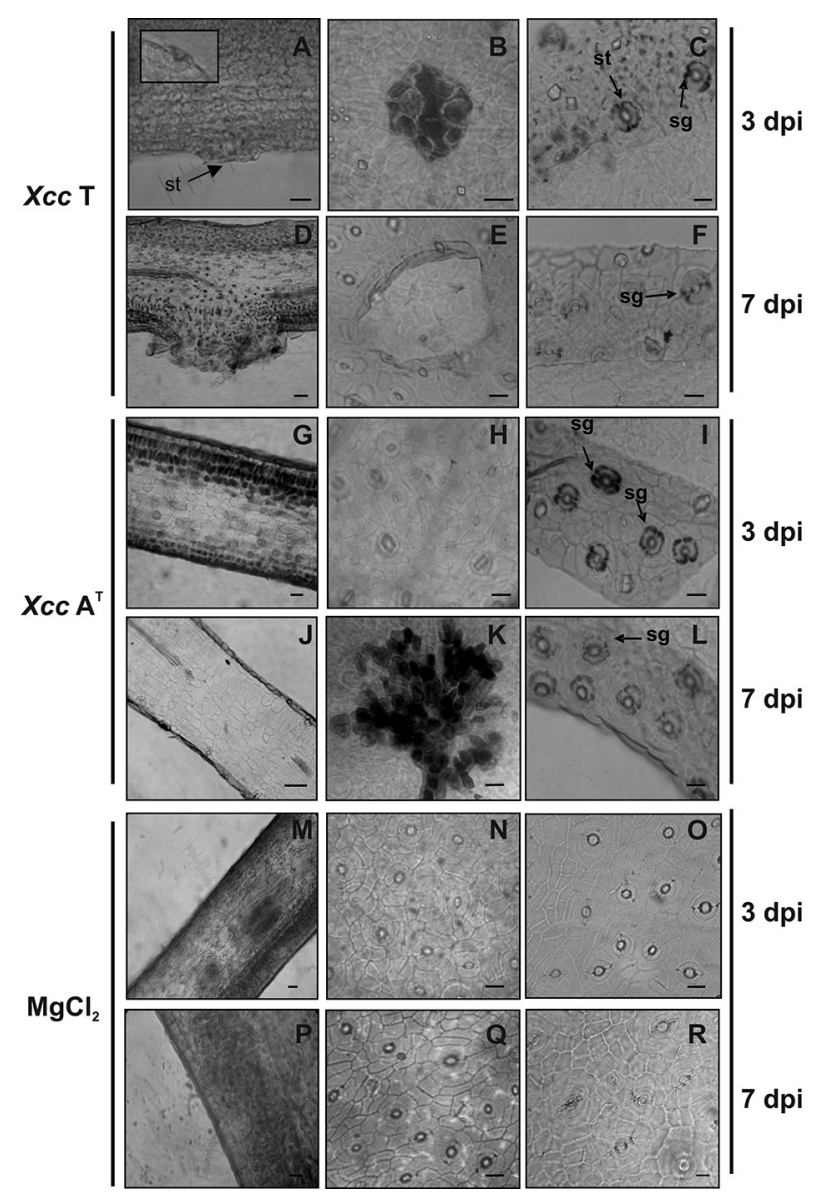

Figure 2 - Histopathologic analysis of Citrus limon leaves inoculated with virulent (Xcc T) or avirulent (Xcc A) Xanthomonas citri subsp. citri isolates on the 3 and 7 day post-inoculations (dpi). Crosssections of leaves inoculated with $X c c T(A, D)$ and $X c c A^{\top}(G, J)$, and control leaves (M, P); a detailed close-up of stomata is included as insert in A. Paradermal views of leaves inoculated with Xcc $T$ $(B, E), X c c A^{\top}(H, K)$, or control leaves (N, Q). Histochemical Lugol test in leaves inoculated with $X c c T(C, F), X c c A^{\top}(I, L)$ or control leaves $(0, R)$. Arrows indicate stomata (st) or starch accumulation (sg); scale bars: $15 \mu \mathrm{m}$.

genome a gene coding for a protein similar to natriuretic plant proteins, which are involved in the regulation of cell growth and homeostasis (Gottig et al., 2008). This protein was shown to alter host physiological responses by means of starch granule degradation in the stomatal guard cells of the plant, causing stomatal openings thereof (Gottig et al., 2008). It is possible that this protein is defective or absent in $X c c \mathrm{~A}^{\mathrm{T}}$, leading to starch accumulation in stoma cells which then hamper the entry of the pathogen.

The avirulent $X c c \mathrm{~A}^{\mathrm{T}}$ elicits a distinct gene expression pattern in the interaction with $C$. limon

To find out what genes are involved in the interaction between $C$. limon and the new $X c c \mathrm{~A}^{\mathrm{T}}$ isolate, a transcript profile was attained through cDNA amplified fragment length polymorphism (cDNA-AFLP) technique, as a first approach to elucidate certain of the mechanisms involved in this specifically induced interaction. This study was carried out $48 \mathrm{~h}$ post-inoculation (hpi), comparing the gene profile induced by the avirulent Xcc $\mathrm{A}^{\mathrm{T}}$ isolate with those produced by the virulent strain $(X c c \mathrm{~T})$ or mock inoculation with $\mathrm{MgCl}_{2}$. Out of 752 fragments derived from transcripts (TDFs) observed in silver-stained cDNA-AFLP gels, 121 TDFs were specifically induced or repressed by virulent $(X c c \mathrm{~T})$ and avirulent $\left(X c c \mathrm{~A}^{\mathrm{T}}\right)$ isolates. Most of the up-regulated TDFs were observed when the plant was challenged with the virulent isolate Xcc T $(47 \%)$; the reverse was true for down-regulated TDFs, as their lowest number was recorded in this case $(6 \%$ ) (Table 1). By contrast, in the interaction with the $X c c \mathrm{~A}^{\mathrm{T}}$ isolate, the numbers of up-regulated $(26 \%)$ and down-regulated $(21 \%)$ TDFs were similar (Table 1). A total of 62 differential TDFs sequences were successfully obtained. Table 1 shows the similarities of TDFs differentially expressed in response to either $X c c \mathrm{~T}$ or $X c c \mathrm{~A}^{\mathrm{T}}$ infection. The expression level of eight TDFs randomly selected from Table 1 was validated by qRT-PCR (Figure 3). As much as $18 \%$ of the TDFs did not show any significant similarity to known proteins. The next most abundant group was composed of TDFs with significant similarity to resistance genes $(15 \%)$ and genes involved in plant metabolism (15\%). The other TDFs were identified as being similar to genes involved in transcription and translation (13\%), energy (10\%), pathway signaling (5\%), structural proteins $(5 \%)$ and transport mechanisms $(2 \%)$. Other TDF groups were linked with citrus EST (11\%) or uncharacterized proteins $(8 \%)$ in the database.

Some TDFs differentially expressed in the interactions are involved in the same mechanisms; for example, genes encoding proteins of the light-harvesting complex of photosystem II (PSII) (Table 1, Cit 26, Cit 32 and Cit 89). It has been shown that the PSII system plays an important role in preventing the accumulation of reactive oxygen species (ROS) (Asada, 1999), and it also seems to participate in both compatible and incompatible plant pathogen interactions (Baldo et al., 2010).

In the interaction with the virulent isolate, up-regulated genes involved in cell cycle, growth and differentiation (and related with hyperplasia and hypertrophy) were identified, as has been previously described (Cernadas et al., 2008).

Interestingly, one of the TDFs induced by Xcc T showed sequence similarity to an MYB transcription factor (Cit 102). Baldo et al. (2010) also found a TDF homologue to MYB 11 in Malus domestica, which was overexpressed in susceptible cultivars after inoculation with Erwinia amylovora. In the same way, two MYB genes in Arabidopsis thaliana were specifically induced by Type 3 effector proteins, and they negatively regulated phenylpropanoid metabolism (Preston et al., 2004). They are widely distributed in plants and have been reported to be involved in the ABA-response and to have interactions 


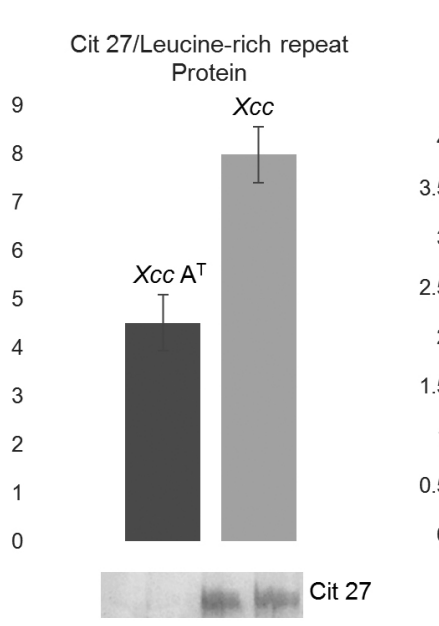

Cit $102 /$ Myb transccriptional
regulator helix turn helix-type

$$
\begin{array}{r}
10 \\
9 \\
8 \\
7 \\
6 \\
5 \\
4 \\
3 \\
2 \\
1
\end{array}
$$$$
6
$$$$
5
$$

0

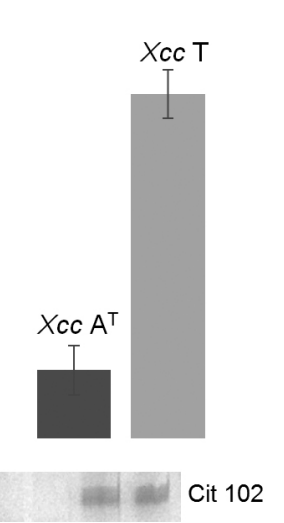

Cit 64/CVP2 putative, type I inositol 1,4,5-trisphosphate 5-phosphatase

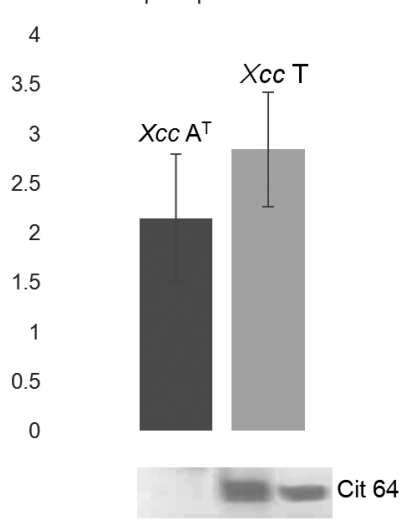

Cit 62/Serine/threonineprotein kinase

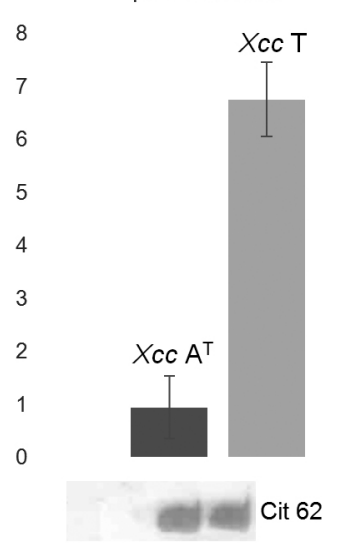

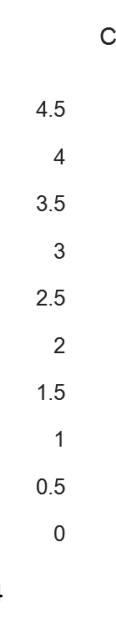

Cit 63/Protein related to nitrogen metabolism
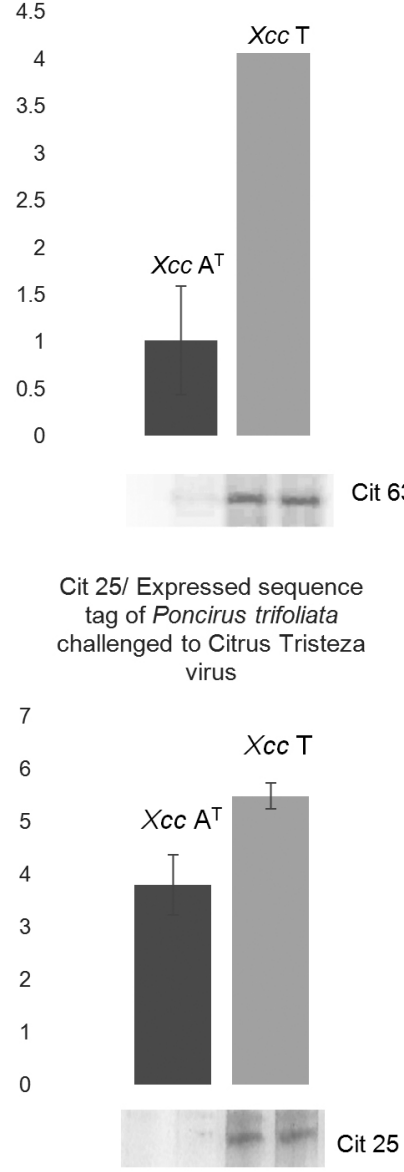

0
Cit 3/ Miraculin

6

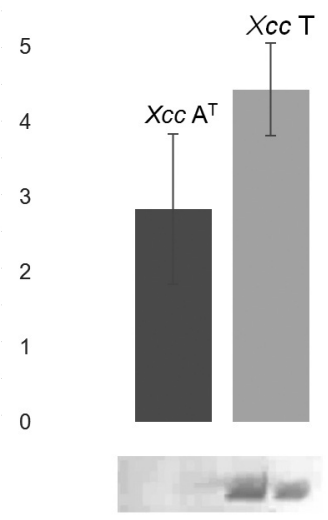

Cit 3

Figure 3 - Quantitative real time retrotranscription- PCR (RT-PCR) analysis of randomly selected transcript derived fragments (TDF) expressed diferentially during Xcc/ Citrus limon interaction. Relative expression of 8 randomly selected TDF (Cit 27, 64, 63, 3, 102, 62, 25 and 35) was quantified through quantitative real time RT-PCR using the $2^{-\Delta \Delta C t}$ method to validate the expression level observed in cDNA-AFLP analysis. All data were normalized using a plant cytochrome oxidase (COX) gene. The mean expression value was calculated for every TDF with three replications. The corresponding signal in a cDNA-AFLP analysis is included for each target.

with other transcription factors (Ambawat et al., 2013). In this interaction, one TDF similar to a lipoxygenase (Cit 29) was also induced. Lipoxygenase (LOX) has been identified as generating highly cytotoxic compounds like unsaturated aldehydes and lipid hydroperoxides, which interact with transition metals to produce corrosive radicals (Brash, 1999). These compounds could produce damage in the membrane by an alternative way to the oxidative burst produced during hypersensitivity reactions (HR) of an incompatible interaction (Adam et al., 1989; Porter et al., 1995; Mittler et al., 1996). However, the LOX mechanism has been proven to be associated with plant-pathogen interaction, and has been observed in both compatible and incompatible interactions (Jalloul et al., 2002). In concordance with Chiesa et al. (2013), we could say that it is possible that $X c c \mathrm{~T}$ inactivates ROS mechanism; nonetheless, the plant can activate another defense pathway, such as the LOX mechanism.
As expected, many of the TDFs expressed differentially during the interaction between $C$. limon and Xcc $\mathrm{A}^{\mathrm{T}}$ were found to be related in some way to resistance and plant defense response. Xcc $\mathrm{A}^{\mathrm{T}}$ induced a TDF similar to plant receptor-like serine threonine kinase (RLSTK) (Cit 34). This receptor recognizes molecules of pathogens and activates signals triggering plant defense responses; such is the case of rice bacterial blight resistance gene product XA21 (Song et al., 1995) and FLS2, a flagellin perception gene in A. thaliana (Gómez-Gómez and Boller, 2000). Another of the TDFs induced by Xcc $\mathrm{A}^{\mathrm{T}}$ was Cit 11, which shows similarity to the enzyme aminocyclopropanecarboxylate oxidase (ACC oxidase), which in turn catalyzes the cleavage of 1-aminocyclopropane-1-carboxylic acid (ACC) into ethylene. It is widely known that ethylene, together with other compounds such as salicylic acid, phytoalexins or reactive oxygen species (ROS), forms part of the complex plant defense mechanism (Joshi and Nayak, 
2011). ACC oxidase induction could indicate that ethylene increases with the interaction between $C$. limon and this avirulent isolate. The activation of this gene in citrus plants was previously described in sweet orange Pera inoculated with $X$. axonopodis pv. aurantifolii (Xaa) pathotype $C$, which does not produce canker in this genotype. Xaa induces ethylene related genes like ACC oxidases, as well as ethylene receptors, ethylene-induced esterase and ethylene response factors $48 \mathrm{hpi}$, and these responses are associated to disease resistance (Cernadas et al., 2008).

Interestingly, Xcc $\mathrm{A}^{\mathrm{T}}$ induced the expression of a TDF similar to a PRP38 splicing factor (Cit 108). Recently, new findings have provided insights into the roles of alternative splicing in the regulation of expression of plant defense genes (Marone et al., 2013). This factor has been generally associated with abiotic stresses such as cold and salinity (Forment et al., 2005; Iida et al., 2004); however, this is the first report of this gene in association with a biotic factor.

On the other hand, in the interaction between $C$. limon and $X c c \mathrm{~A}^{\mathrm{T}}$ a TDF similar to a gene coding for SNARE proteins (Cit 90) was suppressed. One of the primary roles of SNARE proteins is to mediate fusion between cellular transport vesicles and the cellular plasma membrane for exocytosis. A study using inhibitors of vesicle trafficking has shown that this inhibition delays pustule development induced by Xcc in sweet orange Pera leaves (Cernadas et al., 2008), so the suppression of this gene would be consistent with the lack of symptoms in $X c c \mathrm{~A}^{\mathrm{T}}$ inoculated leaves.

In conclusion, unlike the virulent type, the avirulent isolate $X c c \mathrm{~A}^{\mathrm{T}}$ did not prevent the development of physical barriers, such as starch accumulation or cell wall thickening, both events associated with plant defense mechanisms. Differences in gene expression patterns of infected plants, together with the close genetic relationship between these two isolates, could serve as the basis for developing different hypotheses related to the resistance or susceptibility mechanisms responsible for the different infection patterns that these two isolates exhibit. However, a high-throughput sequencing approach will be needed to get a more complete picture of differences in the plant molecular response to both Xcc isolates.

\section{Acknowledgments}

This project was partially supported by the EEAOC (Obispo Colombres Agro-Industrial Experimental Station) Citrus Program. We especially thank Dr. Welin (EEAOC, Argentina) and Miss Adriana Manes (English teacher) for the critical reading of this manuscript and for reviewing the English version of the manuscript.

\section{References}

Adam, A.; Farkas, T.; Somlyai, G.; Hevesi, M.; Kiraly, Z. 1989. Consequence of $\mathrm{O}_{2}$ generation during a bacterially induced hypersensitive reaction in tobacco: deterioration of membrane lipid. Physiological and Molecular Plant Pathology 34: 13-26.
Ambawat, S.; Sharma, P.; Yadav, N.; Yadav, R. 2013. MYB transcription factor genes as regulators for plant responses: an overview. Physiololgy and Molecular Biology Plants 19: $307-$ 321.

Asada, K. 1999. The water-water cycle in chloroplasts: scavenging of active oxygens and dissipation of excess photons. Annual Review of Plant Physiology and Plant Molecular Biology 50: 601-639.

Baldo, A.; Norelli, J.L.; Farrell, R.E.; Bassett, C.L.; Aldwinckle, H.S.; Malnoy, M. 2010. Identification of genes differentially expressed during interaction of resistant and susceptible apple cultivars (Malus $\times$ domestica) with Erwinia amylovora. BMC Plant Biology 10: 1.

Bertani, R.P.; Perera, M.F.; Arias, M.E.; Luque, C.; Funes, C.; González, V.; Cuenya, M.I.; Ploper, D.L.; Castagnaro, A.P. 2014. A study of the sugarcane yellow leaf disease in Argentina. Plant Disease 98: 1036-1042.

Brash, A. 1999. Lipoxygenases: occurrence, functions, catalysis, and acquisition of substrate. Journal of Biological Chemistry 274: 23679-23682.

Brunings, A.M.; Gabriel, D.W. 2003. Xanthomonas citri : breaking the surface. Molecular Plant Pathology 4: 141-157.

Cernadas, R.A.; Camillo, L.R.; Benedetti, C.E. 2008. Transcriptional analysis of the sweet orange interaction with the citrus canker pathogens Xanthomonas axonopodis pv. citri and Xanthomonas axonopodis pv. aurantifolii. Molecular Plant Pathology 9: 609-631.

Chiesa, M.; Siciliano, M.F.; Ornella, L.; Roeschlin, R.A.; Favaro, M.A.; Pino Delgado, N.; Sendín, L.N.; Orce, I.G.; Ploper, L.D.; Vojnov, A.A.; Gadea Vacas, J.; Filippone, M.P.; Castagnaro, A.P.; Marano, M.R. 2013. Characterization of a variant of Xanthomonas citri subsp. citri that triggers a host-specific defense response. Phytopathology 103: 555-564.

D' Ambrogio de Argüeso, A. 1986. Manual of Vegetal Histology Technics. Ed. Hemisferio Sur, Buenos Aires, Argentina.

Forment, J.; Gadea, J.; Huerta, L. 2005. Development of a citrus genome-wide EST collection and cDNA microarray as resources for genomic studies. Plant Molecular Biology 57: 375-391.

Graham, J.H.; Gottwald, T.R.; Cubero J.; Achor, D.S. 2004. Xanthomonas axonopodis pv. citri : factors affecting successful eradication of citrus canker. Molecular Plant Pathology 5: 1-15.

Gómez-Gómez, L.; Boller, T. 2000. FLS2: an LRR receptor-like kinase involved in the perception of the bacterial elicitor flagellin in Arabidopsis. Molecular Cell 5: 1003-1011.

Gottig, N.; Garavaglia, B.S.; Daurelio, L.D.; Valentine, A.; Gehring, C.; Orellano, E.G.; Ottado, J. 2008. Xanthomonas axonopodis pv. citri uses a plant natriuretic peptide-like protein to modify host homeostasis. Proceedings of the National Academy of Sciences of the United States of America 105: 18631-18636.

Gottwald, T.; Graham, J.; Bock, C.; Bonnc, G.; Civerolo, E.; Irey, M.; Leite, R.; McColluma, G.; Parker, P.; Ramallo, J.; Riley, T.; Schubert, T.; Stein, B.; Taylor, E. 2009. The epidemiological significance of post-packinghouse survival of Xanthomonas citri subsp. citri for dissemination of Asiatic citrus canker via infected fruit. Crop Protection 28: 508-524.

Gottwald, T.R.; Graham, J.H.; Schubert, T.S. 2002. Citrus canker: the pathogen and its impact. Plant Health Progress. DOI: 10.1094/PHP-2002-0812-01-RV. 
Gottwald, T.R. 1993. Differential host range reaction of Citrus and citrus relatives to citrus canker and citrus bacterial spot determined by leaf mesophyll susceptibility. Plant Disease 77: 1004.

Iida, K.; Seki, M.; Sakurai, T.; Satou, M.; Akiyama, K.; Toyoda, T.; Konagaya, A.; Shinozaki, K. 2004. Genome-wide analysis of alternative pre-mRNA splicing in Arabidopsis thaliana based on full-length cDNA sequences. Nucleic Acids Research 32: 50965103.

Jalloul, A.; Montillet, J.L.; Assigbetsé, K.; Agnel, J.P.; Delannoy, E.; Triantaphylides, C.; Daniel, J.F.; Marmey, P.; Geiger, J.P.; Nicole, M. 2002. Lipid peroxidation in cotton: Xanthomonas interactions and the role of lipoxygenases during the hypersensitive reaction. Plant Journal 32: 1-12.

Joshi, R.K.; Nayak, S. 2011. Functional characterization and signal transduction ability of nucleotide-binding site-leucinerich repeat resistance genes in plants. Genetic and Molecular Research 10: 2637-2652.

Li, W.; Hartung, J.S.; Levy, L. 2005. Quantitative real-time PCR for detection and identification of Candidatus Liberibacter species associated with citrus huanglongbing. Journal of Microbiological Methods 66: 104-115.

Livak, K.J.; Schmittgen, T.D. 2001. Analysis of relative gene expression data using real-time quantitative PCR and the 2(-Delta Delta C(T)) Method. Methods 25: 402-408.

Marone, D.; Russo, M.; Laido, G.; Leonardis, A.M.; Mastrangelo, A.M. 2013. Plant Nucleotide Binding Site-Leucine-Rich Repeat (NBS-LRR) genes: active guardians in host defense responses. International Journal of Molecular Science 14: 7302-7326.

Mittler, R.; Shulaev, V.; Seskar, M.; Lam, E. 1996. Inhibition of programmed cell death in tobacco plants during a pathogeninduced hypersensitive response at low oxygen pressure. Plant Cell 8: 1991-2001.

Pardo, E.M.; Grellet, C.F.; Salazar, S.M.; Castagnaro, A.P.; Ricci, J.C.; Arias, M.E. 2012. Histopathology of the resistance to Colletotrichum gloeosporioides of wild strawberries and species related to commercial strawberry. Australian Journal of Crop Science 6: 1147-1153.
Porter, N.A.; Caldwell, S.A.; Mills, K.A. 1995. Mechanisms of free radical oxidation of unsaturated lipids. Lipids 30: 277-290.

Preston, J.; Wheeler, J.; Heazlewood, J.; Li, S.F.; Parish, R.W. 2004. AtMYB32 is required for normal pollen development in Arabidopsis thaliana. Plant Journal 40: 979-995.

Sambrook, J.; Fritsch, E.F.; Maniatis, T. 1989. Molecular Cloning: A Laboratory Manual. 2ed. Cold Spring Harbor Laboratory Press, New York, NY, USA.

Sendín, L.N.; Filippone, M.P.; Orce, I.G.; Rigano, L.; Enrique, R.; Peña, L.; Vojnov, A.A.; Marano, M.R.; Castagnaro, A.P. 2011. Transient expression of pepper Bs2 gene in Citrus limon as an approach to evaluate its utility for management of citrus canker disease. Plant Pathology 61: 648-657.

Song, W.Y.; Wang, G.L.; Chen, L.; Kim, K.S.; Holstein, T.; Wang, B.; Zhai, Z.; Zhu, L.H.; Fauquet, C.; Ronald, P.C. 1995. The rice disease resistance gene Xa-21 encoded a receptor kinase-like protein. Science 270: 1804-1806.

Van Sluys, M.; Monteiro-Vitorello, C.B.; Camargo, L.E.; Menck, C.F.M.; Silva, A.C.R.; Ferro, J.A.; Oliveira, M.C.; Setubal, J.C.; Kitajima, J.P.; Simpson, A.J. 2002. Comparative genomic analysis of plant-associated bacteria. Annual Review of Phytopathology 40: 169-189.

Vojnov, A.A.; Amaral, A.M.; Dow, J.M.; Maxwell, J.; Castagnaro, A.P.; Marano, M.R. 2010. Bacteria causing important diseases of citrus utilise distinct modes of pathogenesis to attack a common host. Applied Microbiology and Biotechnology 87: 467-477.

Vuylsteke, M.; Peleman, J.D.; van Eijk, M.J.T. 2007. AFLP-based transcript profiling (cDNA-AFLP) for genome-wide expression analysis. Nature Protocols 2: 1399-1413. 